\title{
Hubungan antara Tingkat Pengetahuan Ibu tentang AKBK dengan Sikap Ibu Mengenai Pemakaian AKBK
}

\author{
Sesilia Triana Dewi \\ Akademi Kebidanan Bunga Bangsaku Bangka
}

Informasi Artikel :

Diterima : 15 November 2020

Direvisi : 19 November 2020

Disetujui : 24 November 2020

"Korespondensi Penulis :

sesiliatrianadewi85@gmail.com

\section{A B S T R A K}

Pemahaman seseorang tentang berbagai alat atau cara kontrasepsi akan berpengaruh terhadap pemakaian alat atau cara KB yang tepat dan efektif dalam rangka pencapaian penurunan TFR tahun 2015. Diketahui akseptor baru jenis kontrasepsi AKBK di wilayah Pangkal Pinang per Agustus 2016 adalah 238 akseptor. Pemakaian AKBK di Kelurahan Semabung Lama, Bukit Intan Pangkal Pinang sendiri masih termasuk rendah yaitu $0,33 \%$. Seseorang akan mempunyai sikap positif terhadap suatu obyek jika mempunyai pengetahuan yang tinggi. Tujuan dari penelitian ini adalah mengetahui hubungan tingkat pengetahaun ibu mengenai alat kontrasepsi bawah kulit (AKBK) dengan sikap ibu mengenai pemakaian AKBK di Kelurahan Semabung Lama, Bukit Intan Pangkal Pinang. Desain penelitian ini menggunakan studi korelasi dengan pendekatan cross sectional, pengambilan data menggunakan kuesioner. Populasi penelitian adalah seluruh ibu yang belum menggunakan KB di Kelurahan Semabung Lama, Bukit Intan Pangkal Pinang sebanyak 198 orang. Pengambilan sampel dengan menggunakan teknik sampling purposive yaitu semua ibu yang ingin ber-KB dari jumlah total populasi ibu yang tidak ber-KB berjumlah 158 orang. Analisa data dalam penilitian ini yaitu secara univariat dan bivariat. Analisa univariat disajikan menggunakan tabel distribusi frekuensi sedangkan analisa bivariat menggunakan uji chi square. Hasil penelitian diperoleh $\mathrm{p}$ value 0,000 yang berarti bahwa ada hubungan tingkat pengetahuan ibu mengenai AKBK dengan sikap ibu mengenai pemakaian AKBK di Kelurahan Semabung Lama, Bukit Intan Pangkal Pinang. Bagi tenaga kesehatan perlu memberikan adanya penyuluhan tentang alat kontrasepsi bawah kulit (AKBK) terutama untuk efek samping dari pemakaian AKBK karena kebanyakan ibu-ibu tidak mau memakai AKBK karena takut akan efek samping yang akan terjadisetelah pemakaian AKBK.

\section{Kata Kunci : Pengetahuan, Sikap, Alat Kontrasepsi Bawah Kulit}

\section{ABSTRACT}

One's understanding of various tools or methods of contraception would affect the use of tools or methods are appropriate and effective family planning in order to achieve reduction in TFR in 2015. It is known that the new acceptors for AKBK contraception in the Pangkal Pinang region as of August 2016 were 238 acceptors. The use of AKBK in Semabung Lama Village, Bukit Intan Pangkal Pinang itself is still low, namely 0.33\%. Someone will have a positive attitude towards an object if it has a high knowledge. The purpose of this study was to determine the relationship knowledge level mother about implant with the attitude of mothers about use in the in Semabung Lama Village, Bukit Intan Pangkal Pinang. The design of this study using a correlation study with cross sectional approach, data collection using questionnaires. The study population was all mothers who do not use family planning in the Semabung Lama Village, Bukit Intan 
Pangkal Pinang of 198 people. Sampling using purposive sampling technique that all women who want family planning from a total population of mothers with no family planning totaled 158 people. Analysis of the data in this research the univariate and bivariate. Univariate analysis is presented using frequency distribution tables while the bivariate analysis using chi square test. The results obtained by using the chi-square $p$ value 0.000, which means that there is a level of knowledge about implant mothers with maternal attitudes about the use of the Village fro implant Semabung Lama Village, Bukit Intan Pangkal Pinang. For health professionals need to provide the counseling on implant mainly for side effects from the use implant because most mothers do not want to wear implant for fear of side effects that will occur after the use implant

\section{Keywords: Knowledge, Attitudes, implant}

\section{PENDAHULUAN}

Paradigma baru program Keluarga Berencana Nasional (KBN) telah diubah visinya dari mewujudkan norma keluarga kecil bahagia sejahtera (NKKBS) menjadi visi untuk mewujudkan "keluarga berkualitas tahun 2015". Keluarga yang berkualitas adalah yang sejahtera, sehat, maju, mandiri, memiliki jumlah anak yang ideal, berwawasan ke depan, bertanggung jawab, harmonis dan bertakwa kepada Tuhan Yang Maha Esa. Berdasarkan visi dan misi tersebut, program KBN mempunyai kontribusi penting dalam upaya meningkatkan kualitas penduduk. Badan Koordinasi Keluarga Berencana Nasional (BKKBN) telah mewujudkan keberhasilannya dengan menurunkan angka kelahiran dan pertumbuhan penduduk, juga terpenting adalah keberhasilan mengubah sikap mental dan perilaku masyarakat dalam upaya membangun keluarga berkualitas (Saifuddin, 2006).

Hasil Survey Demografi dan Kesehatan Indonesia (SDKI) tahun 2016, angka prevalensi penggunaan kontrasepsi pada pasangan usia subur di Indonesia sudah mengalami peningkatan , yakni dari 61,90\% pada tahun 2012 menjadi $63,60 \%$ pada tahun 2016. Pengunaan KB suntik sebesar $31,6 \%$, pil $13,2 \%$, IUD 4,8\%, AKBK $4,3 \%$, kondom $1,3 \%$, kontrasepsi mantap wanita (Medis Operasi Wanita) 3,1\% dan kontrasepsi mantap pria (Medis Operasi Pria) 0,2\%, pantang berkala $1,5 \%$, senggama terputus $2,2 \%$ dan metode lainnya $0,4 \%$.

Meningkatnya tingkat pemakaian alat kontrasepsi (Contraceptive prevalence rate/CPR) secara besar-besaran jelas akan mengalami kendala. Pilihannya adalah mengarah pemakaian kontrasepsi efektif jangka panjang yaitu salah satunya alat kontrasepsi bawah kulit (AKBK), karena dianggap lebih mempunyai efektivitas lebih tinggi dibandingkan dengan kontrasepsi hormonal jenis pil maupun suntik tetapi ternyata masih didominasi oleh pemakaian kontrasepsi pil dan suntikan (Tukiran, 2010) .

Alat kontrasepsi bawah kulit merupakan salah satu metode kontrasepsi jangka panjang yang aman digunakan untuk wanita baik yang mempunyai tujuan untuk menunda kehamilan, menjarangkan kehamilan, maupun untuk wanita setelah melahirkan karena tidak mengganggu produksi ASI, pengembalian tingkat kesuburan cepat setelah pencabutan, ibu tidak perlu repotrepot kembali ke tenaga kesehatan untuk memperoleh kebutuhan kontrasepsi karena kontrasepsi implant merupakan metode kontrasepsi jangka panjang (Sujiyatini, 2009).

Berdasarkan data BKKBN Provinsi Kepulauan Bangka Belitung tahun 2016, pengguna AKBK di Pangkal Pinang sebanyak 737 akseptor, sedangkan akseptor kb suntikan sebanyak 2935 akseptor dan pengguna kb pil sebanyak 780 akseptor. Pengetahuan tentang pengendalian kelahiran dan keluarga berencana merupakan salah satu aspek penting kearah pemahaman tentang berbagai alat atau cara kontrasepsi dan selanjutnya berpengaruh terhadap pemakaian alat atau cara KB yang tepat dan efektif dalam rangka pencapaian penurunan TFR tahun mendatang (Badan Pusat Statistik, 2019).

Survei pendahuluan yang dilakukan pada tanggal 28 September - 3 Oktober 2020, di Kelurahan Semabung Lama, Bukit Intan Pangkal Pinang terdapat $1081 \mathrm{ibu}$, sebanyak 152 orang tidak menggunakan KB dan sebanyak 929 ibu menggunakan $\mathrm{KB}$ dengan rincian sebagai berikut metode suntikan 73,19\% (680 orang), MOW $16,25 \%$ (151 orang), IUD 5,48 \% (51 orang), pil $3,55 \%$ (33 orang) dan AKBK 0,43\% (4 orang). Hasil wawancara yang telah dilakukan kepada 10 ibu yang belum menggunakan alat kontrasespi didapatkan hasil 7 (70 \%) ibu mengetahui tentang AKBK meliputi tentang pengertian AKBK, efektifitas, cara kerja, efek samping, indikasi, 
Jurnal Kebidanan :Jurnal Medical Science Ilmu Kesehatan Akademi Kebidanan Budi Mulia Palembang Volume.10 No.2, Desember 2020

kontraindikasi, keuntungan dan kerugian, dari 10 ibu didapatkan 8 (80\%) ibu bersikap kurang menerima AKBK dikarenakan kurang informasi tentang AKBK, takut akan pemakaian, efek samping, anggapan yang salah tentang AKBK. Berdasarkan survey yang telah dilakukan maka peneliti tertarik untuk mengkaji adakah hubungan antara tingkat pengetahuan ibu tentang AKBK dengan sikap ibu mengenai pemakaian AKBK di Kelurahan Semabung Lama, Bukit Intan Pangkal Pinang.

\section{METODE PENELITIAN}

Jenis penelitian ini adalah penelitian observasional analitik. Penelitian observasional analitik yaitu penelitian yang hasilnya tidak hanya berhenti pada taraf menguraikan atau pendiskripsian, akan tetapi dilanjutkan sampai pada taraf pengambilan kesimpulan yang berlaku secara umum serta menerangkan hubungan sebab akibat dan biasanya sudah ada hipotesisnya. Pengambilan keputusannya dengan menggunakan uji statistic (Taufiqurrohman, 2008). Peneliti akan menganalisis tingkat pengetahuan dengan sikap ibu mengenai AKBK.

Populasi dalam penelitian ini adalah seluruh ibu yang belum menggunakan KB di Kelurahan Semabung Lama, Bukit Intan Pangkal Pinang sebanyak 198 orang.

Sampel dalam penelitian ini adalah semua ibu yang ingin ber-KB dari jumlah total populasi ibu yang tidak ber-KB. Teknik pengambilan sampel menggunakan probability dengan teknik sampling purposive yaitu teknik pengambilan sampel didasarkan pada suatu pertimbangan tertentu yang dibuat oleh peniliti sendiri, berdasarkan ciri atau sifat-sifat populasi yang sudah diketahui sebelumnya (Notoatmodjo, 2010). Jumlah sampel dalam penilitian ini yaitu berjumlah $158 \mathrm{ibu}$.

Alat ukur yang digunakan untuk mengukur variabel bebas dan variabel terikat dalam penelitian ini adalah kuesioner. Kuesioner adalah sejumlah pertanyaan tertulis yang digunakan untuk memperoleh informasi dari responden dalam arti laporan tentang pribadinya atau hal-hal yang ia ketahui (Arikunto, 2006).

Analisa univariat digunakan untuk melihat distribusi frekuensi dari masing-masing variabel, baik variabel dependen maupun variabel independen (Notoatmodjo, 2010). Dalam penelitian ini variabel dependen adalah sikap ibu mangenai pemakaian alat kontrasepsi bawah kulit (AKBK), sedangkan variabel independen adalah tingkat pengetahuan ibu mengenai alat kontrasepsi bawah kulit (AKBK)

Analisa bivariat digunakan untuk melihat hubungan antara variabel dependen (sikap ibu mengenai pemakaian AKBK) maupun variabel independen (tingkat pengetahuan ibu mengenai AKBK). Untuk menguji tingkat kemaknaan dilakukan uji statistic Chi Square (x2) dengan batas kemaknaan $(\alpha)=0,05$, confidence interval $(C I)=95 \%$ yang menggunakan sistem komputerisasi. Keputusan dari pengujian ChiSquare yaitu jika nilai $p$ value $\leq \alpha$ : Ho ditolak dan Ha diterima yang berarti ada hubungan yang bermakna antara tingkat pengetahuan ibu mengenai AKBK dengan sikap ibu mengenai pemakaian AKBK dan bila $p$ Value $>\alpha$ : Ha ditolak dan Ho diterima yang berarti tidak ada hubungan yang bermakna antara tingkat pengetahuan ibu mengenai AKBK dengan sikap ibu mengenai pemakaian AKBK.

HASIL PENELITIAN

1. Analisa Univariat

a. Distribusi Frekuensi Tingkat Pengetahuan Ibu Mengenai AKBK

Tabel1.Distribusi frekuensi tingkat pengetahuan ibu mengenai AKBK di Kelurahan Semabung Lama, Bukit Intan Pangkal Pinang

\begin{tabular}{rcc}
\hline Kategori & Frekuensi & Persentase \\
\hline Rendah & 0 & $0,0 \%$ \\
Sedang & 26 & $16,5 \%$ \\
Tinggi & 132 & $83,5 \%$ \\
\hline Jumlah & 158 & $100,0 \%$ \\
\hline
\end{tabular}

Tabel di atas menunjukkan bahwa hampir seluruh responden memiliki tingkat pengetahuan yang tinggi yaitu sebanyak 132 orang $(83,5 \%)$.

\section{b. Distribusi Frekuensi Sikap Ibu Mengenai Pemakaian AKBK}

Tabel 2 Distribusi sikap ibu mengenai AKBK di Kelurahan Semabung Lama, Bukit Intan Pangkal Pinang

\begin{tabular}{ccc}
\hline Kategori & Frekuensi & Persentase \\
\hline Sikap Negatif & 55 & $34,8 \%$ \\
Sikap Positif & 103 & $65,2 \%$ \\
\hline Jumlah & 158 & $100,0 \%$ \\
\hline
\end{tabular}

Berdasarkan tabel di atas diketahui bahwa sebagian besar dari responden memiliki sikap yang positif mengenai pemakaian AKBK yaitu sebanyak 103 orang $(65,2 \%)$ dari keseluruhan responden. 
2. Analisa Bivariat

Tabel 3. Distribusi tingkat pengetahuan ibu mengenai alat kontrasepsi bawah kulit (AKBK) dengan sikap ibu mengenai AKBK di Kelurahan Semabung Lama, Bukit Intan Pangkal Pinang.

\begin{tabular}{lccccccc}
\hline & \multicolumn{9}{c}{ Sikap Ibu } & \multicolumn{2}{c}{ Total } & \multirow{2}{*}{ P } \\
\cline { 2 - 6 } Pengetahuan & \multicolumn{2}{c}{ Sikap } & \multicolumn{2}{c}{ Sikap } & \multirow{2}{*}{ Total } & \\
& Negatif & \multicolumn{2}{c}{ Positif } & & & \\
\cline { 2 - 7 } & $\mathbf{f}$ & $\mathbf{\%}$ & $\mathbf{f}$ & $\mathbf{\%}$ & $\mathbf{f}$ & $\mathbf{\%}$ & \\
\hline Rendah & 0 & 0,0 & 0 & 0 & 0 & 0,0 & 0,000 \\
Sedang & 17 & 65,4 & 9 & 34,6 & 26 & 100,0 & \\
Tinggi & 38 & 28,8 & 94 & 71,2 & 132 & 100,0 & \\
\hline Total & 55 & 34,8 & 103 & 65,2 & 158 & 100,0 & \\
\hline
\end{tabular}

Tabel di atas menunjukan pada ibu yang memiliki sikap positif yang berpengetahuan sedang ada $34,6 \%$ dan yang berpengetahuan tinggi ada $71,2 \%$. Hal tersebut terlihat bahwa sikap yang positif ada pada ibu dengan tingkat pengetahuan tinggi. Ibu yang memiliki sikap negatif yang berpengetahuan sedang ada $65,4 \%$ dan yang berpengetahuan tinggi ada $28,8 \%$. Hal tersebut terlihat bahwa sikap yang negatif ada pada ibu dengan tinggkat pengetahuan sedang. Hasil analisis statistik dengan menggunakan uji Chi Square diperoleh p value sebesar 0,000. Nilai $\mathrm{p}$ value $(0,000)$ menunjukan kurang dari 0,05 maka Ho ditolak yang berarti ada hubungan anntara tingkat pengetahuan ibu mengenai AKBK dengan sikap ibu mengenai pemakaian AKBK di Kelurahan Semabung Lama, Bukit Intan Pangkal Pinang.

\section{PEMBAHASAN}

1. Tingkat pengetahuan ibu mengenai alat kontrasepsi bawah kulit (AKBK) di Kelurahan Semabung Lama, Bukit Intan Pangkal Pinang

Tingkat pengetahuan ibu mengenai alat kontrasepsi bawah kulit (AKBK) menunjukkan tingkat pengetahuan sebagian besar tinggi yaitu sebanyak 158 yang dijadikan responden terdapat $132 \mathrm{ibu}(83,5 \%)$ mempunyai tingkat pengetahuan tinggi dan $26 \mathrm{ibu}(16,5 \%)$ mempunyai tingkat pengetahuan sedang dari keseluruhan responden. Pengetahuan ibu yang sebagian besar tinggi ini didukung oleh adanya penyuluhan yang diberikan oleh petugas kesehatan tentang AKBK pada kegiatan PKK yang biasa diadakan, serta informasi-informasi baik dari media elektronik maupun media cetak misalnya melalui televisi dan pamflet-pamflet tentang AKBK.

Faktor yang mempengaruhi pengetahuan salah satunya adalah usia. Diketahui bahwa sebagian dari responden berusia 20-35 tahun yaitu sebanyak 80 ibu $(50,6 \%)$ dari keseluruhan responden. Umur seseorang menunjukan kematangan diri seseorang, semakin cukup umur, tingkat kematangan dan kekuatan seseoarang akan lebih matang dalam berfikir. Dilihat dari sudut pandang kepercayaan masyarakat seseorang yang lebih dewasa dipercaya dari orang yang belum tinggi kedewasaannya.

Pengetahuan seseorang juga dipengaruhi oleh tingkat pendidikan, diketahui bahwa sebagian dari responden memiliki tingkat pendidikan tamat SLTA yaitu 68 ibu $(43,0 \%)$, tingkat pendidikan tamat SLTA cukup memberikan kemudahan kepada responden untuk memahami informasi yang diterima tentang AKBK. Tingkat pendidikan SLTA yang memberikan bekal kepada responden untuk memahami suatu informasi dengan cukup baik dibandingkan tingkat sebelumnya, karena pengetahuan itu sendiri dipengaruhi oleh pendidikan formal. Pengetahuan sangat erat hubungannya dengann pendidikan, dimana diharapkan dengan pendidikan yang tinggi maka orang tersebut akan semakin luas pula pengetahuannya. Akan tetapi perlu ditekankan, bukan berarti seseoarang yang berpendidikan rendah mutlak berpengetahuan rendah pula. Hal ini mengingat bahwa peningkatan pengetahuan tidak mutlak diperoleh dari pendidikan formal saja tetapi dari pendidikan non formal.

\section{Sikap ibu mengenai pemakaian AKBK di Kelurahan Semabung Lama, Bukit Intan Pangkal Pinang}

Diketahui bahwa sebagian besar dari responden bersikap positif mengenai pemakaian AKBK yaitu sebanyak 158 ibu yang menjadi responden, didapat $103 \mathrm{ibu}(65,2 \%)$ memiliki sikap positif dan 55 ibu $(34,8 \%)$ memiliki sikap negatif mengenai pemakaian AKBK dari keseluruhan responden. Sebagian besar responden mempunyai sikap positif. Hal ini menunjukan bahwa kecenderungan responden berfikir untuk menerima pemakaian AKBK. Sesuai dengan pendapat Aiken (dalam Mitchell, 1990) bahwa sikap adalah suatu predisposisi yang dipelajari untuk merespon secara konsisten, baik positif maupun negatif terhadap suatu objek.

Sikap juga dikatakan sebagai suatu respons evaluatif. Respons hanya akan timbul apabila individu dihadapkan pada suatu stimulus yang 
menghendaki adanya reaksi individual. Respon evaluatif berarti bahwa bentuk reaksi yang dinyatakan sebagai sikap itu timbulnya didasari oleh proses evaluasi dalam diri individu yang memberi kesimpulan terhadap stimulus dalam bentuk nilai baik-buruk, positif-negatif, menyenangkan-tidak menyenangkan, yang kemudian mengkristal sebagai potensi reaksi terhadap obyek.Menurut Azwar (2010) sikap sosial terbentuk dari adanya interaksi sosial yang dialami oleh individu. Interaksi sosial mengandung arti lebih daripada sekedar adanya kontak sosial dan hubungan antar individu sebagai anggota kelompok sosial, dalam interaksi sosial terjadi hubungan saling mempengaruhi di antara individu yang satu dengan individu yang lainnya, terjadi hubungan timbal balik yang turut mempengaruhi pola masing-masing individu. Interaksi sosial meliputi hubungan antara individu dengan lingkungan fisik maupun lingkungan psikologis, dalam interaksi sosialnya individu bereaksi membentuk pola sikap tertentu terhadap berbagai obyek psikologis yang dihadapinya.

Berdasarkan hasil penelitian sebagian besar responden bersikap positif terhadap pemakaian AKBK ini dipengaruhi oleh faktor media massa. Ketersediaan pemenuhan media massa di Kelurahan Semabung Lama,Bukit Intan Pangkal Pinang baik media cetak maupun media elektronik sangat mudah sehingga sangat berpengaruh dalam pembentukan sikap positif responden mengenai pemakaian AKBK. Sarana komunikasi, berbagai bentuk media massa seperti televisi, radio, surat kabar dan lain-lain, juga mempunyai pengaruh besar dalam pembentukan opini dan kepercayaan orang. Media massa sebagai panyampaian informasi juga membawa pula pesan-pesan yang berisi sugesti yang dapat mengarahkan opini seseorang. Adanya informasi baru mengenai sesuatu hal memberikan landasan kognitif baru bagi terbentuknya sikap terhadap sesuatu.

\section{Hubungan Tingkat Pengetahuan Ibu Mengenai Alat Kontrasepsi Bawah Kulit (AKBK) dengan Sikap Ibu Mengenai Pemakaian AKBK di Kelurahan Semabung Lama, Bukit Intan Pangkal Pinang. \\ Berdasarkan hasil analisis statistik dengan} uji Chi Square diperoleh p value sebesar 0,000. Nilai $\mathrm{p}$ value $(0,000)$ menunjukan kurang dari 0,05 maka Ho ditolak yang berarti ada hubungan antara tingkat pengetahuan ibu mengenai AKBK dengan sikap ibu mengenai pemakaian AKBK di
Kelurahan Semabung Lama, Bukit Intan Pangkal Pinang.

Diketahui ibu yang memiliki sikap positif yang berpengetahuan sedang ada $34,6 \%$ dan yang berpengetahuan tinggi ada $71,2 \%$. Hal tersebut terlihat bahwa sikap yang positif ada pada ibu dengan tingkat pengetahuan tinggi. Ibu yang memiliki sikap negatif yang berpengetahuan sedang ada $65,4 \%$ dan yang berpengetahuan tinggi ada $28,8 \%$. Hal tersebut terlihat bahwa sikap yang negatif ada pada ibu dengan tinggkat pengetahuan sedang.

Pengetahuan pada dasarnya datang dari pengalaman dan dapat diperoleh dari media elektronik dan media cetak, selain itu pengetahuan seseorang dipengaruhi oleh pendidikan, usia, budaya serta lingkungan tempat seorang individu tinggal. Hal ini sesuai dengan pendapat dari Notoatmodjo (2010) bahwa pengetahuan merupakan hasil tahu dan ini terjadi setelah orang melakukan pengindraan terhadap suatu obyek. Pengindraan terjadi melalui panca indera manusia, yakni indera penglihatan, pendengaran, penciuman, rasa dan raba, serta perilaku yang didasari oleh pengetahuan akan lebih langgeng daripada perilaku yang tidak didasari oleh pengetahuan.

Pengetahuan seseorang merupakan salah satu yang memegang peran penting dalam pembentukan sikap. Sikap itu sediri merupakan reaksi atau respon seseorang yang masih tertutup terhadap suatu stimulus atau obyek. Pembentukan sikap diperlukan 3 komponen yaitu komponen kognitif, afektif dan konatif. Komponen kognitif merupakan olahan pikiran manuasia atau seseorang yang akan menghasilkan pengetahuan, pengetahuan ini yang akan menjadi dasar untuk melanjukan stimulus ke komponen afektif dan konatif sehingga akan terbentuk sikap seseorang terhadap suatu obyek. Adanya pengetahuan ibu mengenai AKBK yang tinggi akan membantu ibu memunculkan sikap yang positif mengenai pemakaian AKBK sebelum ibu untuk memutuskan memilih AKBK sebagai metode kontrasepsi yang dipilihnya.

Berdasarkan hasil penelitian meskipun responden memiliki pengetahuan tinggi akan tetapi masih ada yang memiliki sikap negatif yaitu dari 132 responden yang memiliki pengetahuan tinggi ada 38 responden memiliki sikap negatif. Beberapa hal yang memnyebabkan 38 responden memiliki sikap yang negatif mengenai pemakaian AKBK walaupun memiliki pengetahuan yang tinggi diantaranya dipengaruhi oleh karena faktor agama,pengaruh orang lain dan faktor emosional. Hal ini seperti yang 
dikatakan oleh Azwar (2010) bahwa faktor agama mempunyai pengaruh dalam pembentukan sikap dikarenakan konsep moral dan ajaran agama sangat menentukan sistem kepercayaan maka tidaklah mengherankan kalau pada gilirannya kemudian konsep tersebut ikut berperan dalam menentukan sikap individu terhadap sesuatu hal. Sebagian besar reponden berkeyakinan bahwa agama tidak memperbolehkan terhadap pemakaian alat kontrasepsi jenis apapun sehingga mereka lebih memilih mengikuti keuarga berencana dengan meggunakan KB alamiah. Selain itu juga Azwar mengatakan pembentukan sikap juga dipengaruhi dari orang lain, pada umumnya individu cenderung untuk memiliki sikap yang searah dengan orang yang memberikan pengaruh tersebut. Pengalaman-pengalaman orang tentang efeksamping dari pemakaian AKBK membuat rasa takut terlebih dahulu sehingga hal tersebut mempengaruhi ibu bersikap negatif walaupun mempunyai pengetahuan tinggi, ini terlihat pada saat responden memberikan jawaban pada kuisoner sikap yang kebanyakan tidak setuju memakai AKBK karena rasa takut.

\section{KESIMPULAN DAN SARAN \\ Kesimpulan}

Berdasarkan hasil analisis statistik dengan menggunakan uji Chi Square didapat $\mathrm{p}$ value sebesar 0,000 . Nilai $\mathrm{p}$ value $(0,000)$ menunjukan kurang dari 0,05 maka Ho ditolak yang berarti ada hubungan antara tingkat pengetahuan ibu mengenai AKBK dengan sikap ibu mengenai pemakaian AKBK di Kelurahan Semabung Lama, Bukit Intan Pangkal Pinang.

\section{Saran}

1. Bagi Tenaga Kesehatan

Diharapakn dapat memberikan penyuluhan tentang alat kontrasepsi bawah kulit (AKBK) terutama untuk efek samping dari pemakaian AKBK karena kebanyakan ibu-ibu tidak mau memakai AKBK karena takut akan efek samping yang akan terjadi setelah pemakaian AKBK.

2. Bagi Institusi Pendidikan

Hasil penelitian ini dapat dijadikan sebagai dokumentasi agar dapat digunakan untuk bahan perbandingan dalam melaksanakan penelitian. Selain itu juga dapat dijadikan sebagai bahan referensi di perpustakaan, memberikan informasi dan pengetahuan dalam proses belajar mengajar.
3. Bagi Peneliti yang akan datang Diharapkan ke depan dilaksanakan penelitian yang lebih lanjut dalam skala yang lebih luas yaitu meneliti tentang faktor-faktor yang mempengaruhi rendanya pemilihan pemakaian alat kontrasepsi bawah kulit karena pemakaian alat kontrasepsi bawah kulit masih tergolong rendah.

\section{DAFTAR PUSTAKA}

Arikunto, S. 2010. Dasar-dasar evaluasi pendidikan. Jakarta: Bumi Aksara.

Azwar Saifudin. 2010. Sikap manusia teori dan pengukurannya. Edisi ke 2 Cetakan XIV. Yogyakarta: Pustaka Pelajar.

Badan Pusat Statistik (BPS) dan ORC Marco. 2003. Survey demografi dan kesehatan indonesia 2002-2003, Calverton, Maryland, USA: ORC Marco.

Notoatmodjo, 2010. Ilmu perilaku kesehatan. Jakarta: Rineka Cipta.

Saifuddin, 2006. Buku panduan praktis pelayanan kontrasepsi. ed.1, cetakan ke-4. Jakarta. YBPSP.

Sujiyantini, 2009. Panduan lengkap pelayanan KB terkini. Jogyakarta: Nuha Offset.

Taufiqurrohman, M.A. 2008. Pengantar metodologi penelitian untuk kesehatan. Surakarta: LPP UNS dan UNS Press.

Tukiran. 2010. Keluarga berencana dan kesehatan reproduksi. Yogyakarta: Pustaka Pelajar. 
